University of Florida Levin College of Law

UF Law Scholarship Repository

UF Law Faculty Publications

Faculty Scholarship

2008

\title{
China's Competition Policy Reforms: The Anti-Monopoly Law and Beyond
}

Bruce M. Owen

Stanford University

Su Sun

Wentong Zheng

University of Florida Levin College of Law, wtzheng@law.ufl.edu

Follow this and additional works at: https://scholarship.law.ufl.edu/facultypub

Part of the Antitrust and Trade Regulation Commons, and the Comparative and Foreign Law Commons

Recommended Citation

Bruce M. Owen, Su Sun \& Wentong Zheng,China's Competition Policy Reforms: The Anti-Monopoly Law and Beyond, 75 Antitrust L.J. 231 (2008), available at http://scholarship.law.ufl.edu/facultypub/223

This Article is brought to you for free and open access by the Faculty Scholarship at UF Law Scholarship Repository. It has been accepted for inclusion in UF Law Faculty Publications by an authorized administrator of UF Law Scholarship Repository. For more information, please contact kaleita@law.ufl.edu. 


\title{
CHINA'S COMPETITION POLICY REFORMS: THE ANTI-MONOPOLY LAW AND BEYOND
}

\author{
Bruce M. OwEN \\ Su SuN \\ WENTONG ZHENG*
}

\section{INTRODUCTION}

The Supreme Court of the United States once characterized antitrust law as the "Magna Carta" of free enterprise. ${ }^{1}$ By promoting free and fair competition, antitrust law has supported market economies in the West in several important ways. First, it promotes economic efficiency, by making sure that goods are made by the firm that can produce them at lowest cost, and that goods flow to those consumers who value the goods the most. Second, antitrust law seeks to protect customers, both individuals and businesses, against the wealth transfers that accompany the creation and exercise of undue market power. Third, antitrust law is an aspect of broader competition policy, which seeks to promote private competitive markets as alternatives to State-owned enterprises or regulated monopolies.

For countries that have operated under centrally planned economic systems, however, "competition" often is an unfamiliar concept. Such countries must learn the importance of competition as an institution as their centrally planned economies are transformed into market-oriented economies. Increasingly, they look to the antitrust laws developed in Western countries for guidance in designing their competition policies.

* Bruce Owen is the Morris M. Doyle Centennial Professor in Public Policy at Stanford University, and the Gordon Cain Senior Fellow at the Stanford Institute for Economic Policy Research. Su Sun is a Senior Economist at the Washington, D.C. office of Economists Incorporated. Wentong Zheng is an attorney in Washington, D.C. The views expressed in this article are entirely the authors' own and do not reflect the views of the organizations with which the authors are affiliated.

${ }^{1}$ United States v. Topco Assocs., 405 U.S. 596, 610 (1972). 
After China began its historic transition from a centrally planned economy to a market economy in the late 1970 s, it gradually came to realize that good competition policies would be of vital importance to its economic growth. As a result, China began experimenting with reform measures and enacting antitrust laws and regulations aimed at promoting competition in its economy. At first, China adopted a piecemeal approach, passing laws and regulations dealing with isolated competition issues as they arose. As competition issues became increasingly prominent, China recognized the importance of having a comprehensive antitrust law. In 1994, China began its efforts to enact the Anti-Monopoly Law (AML), China's first comprehensive antitrust legislation.

Thirteen years later, on August 30, 2007, China's National People's Congress (NPC) finally adopted the AML. ${ }^{2}$ The AML has provisions found in most other countries' antitrust laws, such as the prohibition of horizontal agreements and abuse of market power, and requirements for pre-merger notifications and reviews. The AML also contains many provisions not typical of antitrust laws, such as provisions regarding State-Owned Enterprises (SOEs) in important economic sectors, trade associations, and monopolies created by government agencies.

The AML was adopted only after a painstaking drafting process, which included numerous drafts, seminars, debates, and behind-the-scenes jockeying. When a law takes so long to enact in China, that usually signifies that it is highly controversial. Indeed, the AML was drafted during a period in which China was trying to consolidate its powerful SOEs in important sectors, there was widespread perception of "excessive" competition, mergers and acquisitions of domestic companies by foreign investors increased concerns, government agencies were responsible for the most significant restrictions on competition, and it was uncertain how the proposed antitrust law would be enforced. These complications prolonged debates on the AML.

These same fundamental issues-and how China deals with themwill determine the effectiveness of the AML and China's future competition policy reforms. The AML reflects many compromises on these issues made to facilitate enactment, and did not resolve the most

2 See Antimonopoly Law of the People's Republic of China (promulgated by the Standing Committee of the National People's Congress on Aug. 30, 2007 and effective Aug. 1, 2008) [hereinafter AML], available at http://www.npc.gov.cn/zgrdw/common/ $z w . j s p$ ?label $=W X Z L K \&$ cid $=371229 \&$ pdmc $=11006$. The translations provided in this article are the authors'. An unofficial English translation is also available as an appendix to Nathan Bush, The PRC Antimonopoly Law: Unanswered Questions and Challenges Ahead, ANTITRUST SourCE, Oct. 2007, http://www.abanet.org/antitrust/at-source/07/10/Oct07Bush 10-18f.pdf. 
controversial issues surrounding the earlier drafts. Those issues will pose continued challenges to China's antitrust enforcers. Understanding these issues, therefore, is crucial to understanding the AML and the factors affecting the future of China's competition policy reforms.

There have been many technical commentaries on the draft AML from the perspective of a Western antitrust practitioner. We do not replicate such efforts. Instead, we review the systemic challenges facing the drafting and enforcement of the AML and China's broader competition policy reforms, and the provisions of the AML that relate to those challenges, i.e., the role of SOEs, perceived excessive competition, mergers and acquisitions of Chinese companies by foreign investors, administrative monopolies, and enforcement.

\section{THE EVOLUTION OF CHINA'S ANTITRUST LAWS}

\section{A. China's Antitrust Laws and Rules Prior to the AML}

Prior to the AML, China's competition policy was contained in a number of laws and administrative rules. The most comprehensive of these is the Anti-Unfair Competition Law, promulgated in $1993 .{ }^{3}$ The Anti-Unfair Competition Law contains some provisions commonly found in antitrust law, such as prohibition of tie-in sales and prohibition of price fixing and bid rigging. But the Anti-Unfair Competition Law also addresses many other issues, including bribery, deceptive advertising, coercive sales, and appropriation of business secrets. To a large extent, the Anti-Unfair Competition Law is more like a consumer protection law than an antitrust law.

Antitrust provisions are also scattered throughout other, more specialized laws. For example, the Commercial Banking Law, passed in 1995, includes an article that prohibits banks from engaging in "improper competition." "The Price Law, passed in 1997, has provisions against "improper pricing behaviors" including price fixing, predatory pricing, and price discrimination. ${ }^{5}$ The Procurement and Bidding Law, passed in

${ }^{3}$ Anti-Unfair Competition Law of the People's Republic of China (promulgated by the Standing Committee of the National People's Congress on Sept. 2, 1993 and effective Dec. 1, 1993). (Translation available by subscription at http://www.chinalawinfo.com.)

${ }^{4}$ Article 9 of the Law of Commercial Banking of the People's Republic of China (effective May 10, 1995, as amended on Dec. 27, 2003), available at http://www.pbc.gov.cn/ rhwg/19981802.htm (official Chinese text).

${ }^{5}$ Article 14 of the Price Law (promulgated by the Standing Committee of the National People's Congress on Dec. 29, 1997 and effective May 1, 1998), available at http://www. gov.cn/ziliao/flfg/2005-09/12/content_31188.htm. (Translation available by subscription at http://www.chinalawinfo.com.) 
1999, prohibits bid rigging. ${ }^{6}$ Most recently, China revised the 2001 Patent Law for the third time, adding provisions under Chapter Six (compulsory licensing) against patent abuse when that abuse excludes or restricts competition.?

More often, competition issues are directly addressed by the issuance of administrative rules and regulations. In some cases administrative rules are used to address new issues that require a quick response. In other cases they provide more detailed interpretations of previously promulgated laws. Some important administrative rules regarding competition issues include the following.

- In 1993, the State Administration of Industry and Commerce (SAIC) issued Certain Provisions on Prohibiting Public Utility Enterprises from Committing Restrictive Acts Against Competition, ${ }^{8}$ intended to rein in widespread abuse of monopoly positions by public utility companies.

- In April 2001, the State Council, China's cabinet, issued the Rules on Prohibiting Regional Blockades in Market Economic Activities. ${ }^{9}$ These Rules address a major form of administrative monopoly in which local government agencies deliberately discriminate against products and services provided from other localities and often simply deny them access to the local market.

- In 2003, the National Development and Reform Commission issued the Provisional Rules on Prevention of Monopoly Pricing. ${ }^{10}$ The Rules prohibit the abuse of "market dominance" and infer dominance from "market share in the relevant market, substitutability of

${ }^{6}$ See Article 32 of the Procurement and Bidding Law (promulgated by the Standing Committee of the National People's Congress on Aug. 30, 1999 and effective Jan. 1, 2000), available at http://xinxiangxian.xx.gov.cn/lmz/juwei/shenji/flfg/kjfg37.htm.

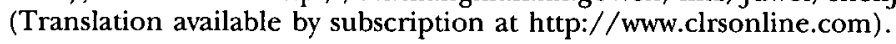

${ }^{7}$ For China's current Patent Law (second revision), see http://www.npc.gov.cn/ was $40 /$ detail? record $=1$ \&channelid $=20179 \&$ searchword $=\% 20(\% 20 \%$ D6\%D0\%BB $\% A A \%$ C8\%CB\%C3\%F1\%B9\%B2\%BA\%CD\%B9\%FA\%D7\%A8\%C0\%FB\%B7\%A8+\% 29+and+\% $28+\mathrm{IDS} \% 3 \mathrm{D} \% 277370^{\prime} \% 20$ ). The third revision is now under review.

${ }^{8}$ See Certain Provisions on Prohibiting Public Utility Enterprises from Committing Restrictive Acts Against Competition (promulgated by the State Administration of Industry and Commerce on Dec. 24, 1993), available at http://www.apeccp.org.tw/doc/China/ Decision/cndec05.html.

${ }^{9}$ See Rules on Prohibiting Regional Blockades in Market Economic Activities (promulgated by the State Council Apr. 29, 2001 and effective Apr. 29, 2001), available at http:// www.people.com.cn/GB/shizheng/20010429/456075.html.

${ }^{10}$ See Interim Provisions on Preventing Acts of Price Monopoly, Order [2003] No. 3 (adopted by the State Planning and Development Commission on June 18, 2003 and effective Nov. 1, 2003), available at http://www.sdpc.gov.cn $/ \mathrm{zcfb} / \mathrm{zcfbl} / \mathrm{zcfbl} 2003 / \mathrm{t} 2005$ 0613_6683.htm. (Translation available by subscription at http://www.chinalawinfo.com.) 
relevant goods, and ease of new entry." The Rules also prohibit price coordination, supply restriction, bid rigging, vertical price restraint, below-cost pricing, and price discrimination as abuses of dominance. Finally, the Rules prohibit government agencies from "illegally intervening" in market price determination.

These regulations generally did not have a clear and credible enforcement mechanism, and their implementation has been largely ineffective. ${ }^{11}$

To address rising concerns about foreign acquisitions of Chinese companies, six government agencies jointly issued the Rules on Acquisitions of Domestic Enterprises by Foreign Investors (M\&A Rules) in 2006. ${ }^{12}$ Article 51 of the M\&A Rules lays out the four conditions under which premerger notification to China's Ministry of Commerce (MOFCOM) and the SAIC is required. The four conditions include thresholds that relate to annual sales, the number of enterprises the foreign party has previously acquired in related industries, the merging parties' market shares before and after the merger. The M\&A Rules, however, suffered from a number of deficiencies. ${ }^{13}$

To aid the implementation of the M\&A Rules, in March 2007 MOFCOM posted on its Web site the Antitrust Filing Guidelines. ${ }^{14}$ The Guidelines mostly resemble similar guidelines and procedures adopted by other jurisdictions and are helpful for parties who wish to understand

11 See, for example, a Ministry of Commerce official's comment in 2004 that regional blockade was the major obstacle in forming a national market, available at http:// www.icn.com.cn/Fujian_w/gnxw/20040623t/gn139079.html, and some National People's Congress Standing Committee members' comments in 2007 on the ineffective regulation of monopoly pricing, http://www.npc.gov.cn/xinwen/lfgz/lfdt/2007-06/26/ content_367777.htm.

12 Rules on Acquisition of Domestic Enterprises by Foreign Investors, http://www. xasmw.com/rule/content.asp?id=254 (unofficial Chinese text). A provisional rule that had essentially the same content on antitrust review was issued in 2003. Provisional Regulations Regarding Mergers and Acquisitions of Domestic Enterprises by Foreign Investors (promulgated by Ministry of Foreign Trade and Economic Cooperation, State Administration of Taxation, State Administration of Industry and Commerce, and State Administration of Foreign Exchange on Mar. 13, 2003 and effective Apr. 12, 2003), available at http://tfs.mofcom.gov.cn/aarticle/date/i/s/200509/20050900366385.html. (Translation available by subscription at http://www.chinalawinfo.com.)

${ }^{13}$ For a brief discussion of some of the problems in the M\&A Rules, such as the use of the number of acquired enterprises "in related industries" and "market shares" as notification thresholds, see Su Sun, Antitrust Review in China's New Merger Regulation, EconoMISTS INK, Winter 2007, available at http://www.ei.com/ink/Winter_2007.pdf.

14 See Antitrust Filing Guidelines, http://tfs.mofcom.gov.cn/aarticle/bb/200704/ 20070404597464.html (official Chinese text). 
when and what to file. The Guidelines' filing requirements, however, have been criticized as overly burdensome to merging parties. ${ }^{15}$

\section{B. THE AML}

As can be seen from the foregoing discussion, China's antitrust laws and regulations prior to the AML were fragmented, vague, and repetitive, and the effectiveness of antitrust enforcement was hampered by the existence of multiple enforcement agencies authorized by different laws. Partly as a response to the shortcomings of its existing antitrust rules, China began its efforts to enact the comprehensive AML to consolidate the antitrust provisions into a uniform set of rules. ${ }^{16}$

Two government agencies, the State Economic and Trade Commission (SETC) and the SAIC, were charged with drafting the AML in 1994, soon after the 1993 Anti-Unfair Competition Law was promulgated. The SETC was abolished in a government restructuring in 2003 and MOFCOM has since taken its place as the main drafter of the AML. ${ }^{17}$ By 2002, a draft had taken shape and soon began circulating in small circles for comment. A number of revisions followed during the next two years, and in March 2004 a draft law was submitted to the State Council Legislative Affairs Office for its review. After several more revisions, a draft was submitted to the NPC Standing Committee for its first review in June 2006, on which the NPC Standing Committee commented. ${ }^{18} \mathrm{~A}$ further revised draft was commented on during the NPC Standing Committee's second review in late June 2007. ${ }^{19}$ The NPC Standing Commit-

15 The ABA Sections of Antitrust Law and International Law and Practice have made detailed comments on the Guidelines. See Am. Bar Ass'n, Comments of the American Bar Association Section of Antitrust Law and Section of International Law on The Guidelines on Antitrust Fillings for Mergers $\mathcal{E}^{2}$ Acquisitions of Domestic Enterprises by Foreign Investors (Mar. 3, 2007), available at http://www.abanet.org/antitrust/at-comments/2007/03-07/commPRC.pdf.

${ }^{16}$ The drafting of a bill in China is usually done by the Commission for Legislative Affairs under the NPC. Other government bodies, such as the State Council and the ministries that would be responsible for enforcing the proposed law, also have the authority to draft a bill. Draft bills are sent to the NPC for its review. Bills can be enacted either by the plenary session of the NPC or by its Standing Committee. There are no legal requirements on the number of NPC reviews a bill must undergo before it can be approved. The number of reviews a bill receives from the NPC will depend on its importance, complexity, and the controversies it presents.

${ }^{17}$ See Ming Shang, China's Competition Policy and Legislation in Development (Apr. 22, 2005), http://tfs.mofcom.gov.cn/aarticle/dzgg/f/200504/20050400081489.html.

${ }^{18}$ The NPC Standing Committee members made a number of comments during their first review. See http://www.npc.gov.cn/zgrdw/common/zw.jsp?label=WXZLK\&\&id=350 218\&pdmc=110106.

${ }^{19}$ For the content of the six added provisions in the latest draft and some NPC Standing Committee members' comments during their second reading, see http:// www.npc.gov.cn/zgrdw/flzt/index.jsp?lmid=15\&dm=1520\&pdmc $=$ ch. 
tee approved the final draft of the AML during its third review on August 30, 2007. ${ }^{20}$

The AML drafting process, though not public and transparent, did involve a small circle of experts and practitioners, both from China and from other parts of the world. Seminars and conferences were held in China and in other jurisdictions, including the United States and Europe. Foreign enforcement officials, scholars, and practicing attorneys frequently spoke at seminars and conferences and commented on the drafts. The American Bar Association alone made several rounds of comments on different drafts of the AML. ${ }^{21}$ The various revisions of the draft AML appear to have incorporated comments by various parties. Through these many rounds of comments and revisions, the AML was improved substantially, and Chinese government officials also seem to have gained more knowledge and better understanding about competition issues generally.

The AML, as approved, consists of eight chapters. ${ }^{22}$ Chapter One describes the general principles of the AML, including objectives, applicability, coverage, the role of SOEs in important sectors, the role of trade associations, and the two proposed antitrust enforcement agencies. Chapter Two describes which monopoly agreements are prohibited and which are exempted. Chapter Three prohibits the abuse of a market dominant position. It provides methods to infer dominance and describes abusive behaviors. Chapter Four provides for agency review of proposed mergers, acquisitions, and joint ventures, and outlines the review procedures. Chapter Five is devoted to prohibitions of anticompetitive activity by government agencies. This chapter incorporates some of the prior administrative rules and focuses in particular on various forms of local protectionism. Chapter Six describes the investigative procedure to be followed by the enforcement agency. Chapter Seven describes lia-

\footnotetext{
${ }^{20}$ An official Chinese text of the AML can be found at http://www.gov.cn/ziliao/flfg/ 2007-08/30/content_732591.htm.

${ }^{21}$ See ABA, Joint Submission of the American Bar Association's Sections of Antitrust Law and International Law and Practice on the Proposed Anti-Monopoly Law of the People's Republic of China (July 15, 2003), available at http://www.abanet.org/antitrust/at-comments/2003/ 07-03/jointsubmission.pdf; see also Am. Bar Ass'n, Joint Submission of the American Bar Association's Sections of Antitrust Law, Intellectual Property Law E International Law and Practice on the Proposed Anti-Monopoly Law of the People's Republic of China, May 20, 2005, available at http://www.abanet.org/antitrust/at-comments/2005/05-05/commentsprc2005wapp.pdf; and the July 2005 Supplement, http://www.abanet.org/antitrust/at-comments/2005/0705/abaprcat2005-2final.pdf.

${ }^{22}$ We made detailed comments on a similar, earlier draft of the AML. See Bruce Owen, Su Sun \& Wentong Zheng, Antitrust in China: The Problem of Incentive Compatibility, $1 \mathrm{~J}$. CoMpetition L. \& ECON. 123 (2005). We agree with much of the commentaries on the draft law offered by the American Bar Association, supra note 21.
} 
bility and penalties for violating the AML. Chapter Eight states that agricultural activities are generally exempted, and that an intellectual property right is not to be regarded as a per se unlawful monopoly but that the abuse of such rights to restrict competition is subject to the AML.

Chapter Eight also states that the effective date of the AML is August 1, 2008. The AML does not specify whether the previous antitrust-related laws and regulations will remain effective after the AML takes effect. However, in China's legal culture, more recent and more general legislation takes precedence over less recent and less general legislation and regulations. It is expected that future antitrust enforcements in China will be based on the AML, and that before August 1, 2008, China will promulgate regulations necessary to implement the AML.

\section{CHINA'S ECONOMIC, REGULATORY, AND LEGAL CONTEXTS}

To understand the fundamental issues giving rise to the challenges facing China's competition policy reforms in general and the drafting and enforcement of the AML in particular, a brief discussion of China's economic, regulatory, and legal contexts in which those issues arise is in order. ${ }^{23}$ The formulation of competition policy in a country does not happen in a vacuum; instead, it is closely tied to the economic, political, and legal contexts of the country. This is particularly so in China. The AML was being drafted-and will be enforced-against the backdrop of China's historic transformation from a centrally planned economy to a market economy.

\section{A. China's Economic Context}

When economic reforms began in 1978, China's economy was dominated by the State, and private enterprises played only a negligible role. With factories essentially being units of the State productive machinery, there was little role for competition. At times the government promoted "labor competition" among factories or production units in an effort to indoctrinate the populace with communist ideology, but competition motivated by profits was condemned as a symptom of corrupt capitalist systems. The subsequent establishment of the household responsibility system in rural areas and the contract responsibility system in SOEs greatly increased the economic incentive to work.

${ }^{23}$ For a somewhat more detailed but less up-to-date discussion, see Owen, Sun \& Zheng, supra note 22. 
In 1992, China significantly accelerated its pace of economic reform after the inspection tour of the southern regions by its paramount leader, Deng Xiaoping. In the fall of 1992, the Fourteenth Congress of the Chinese Communist Party officially declared that the central goal of China's economic reform is to establish a "socialist market economy." In the following decade, far-reaching reform measures were undertaken to overhaul China's SOE sector, taxation, banking, and foreign currency systems. Private enterprises grew rapidly, and large amounts of foreign investment flowed in.

Now, nearly thirty years after the start of economic reform in 1978, China's economic structures have undergone dramatic changes. One of the most significant changes is the relative decline of SOEs and other State-controlled enterprises and the emergence of the private sector. According to a national census completed in 2003 on the composition of China's economic entities, SOEs and enterprises with a controlling share held by the State accounted for 56.2 percent of capital invested and 49.6 percent of annual revenue among three million enterprises that existed on December 31, 2001. ${ }^{24}$ Anecdotal evidence indicates that further economic reform since 2001 has lowered the share of SOEs in China's economy to about one-third. ${ }^{25}$ This is a remarkable contrast with 1978, when all enterprises were State-owned.

Despite the growing role of the private sector in China's economy, private enterprises in China are mostly small. In fact, 99 percent of the enterprises in China are small or medium size, with most of them funded by private investment. ${ }^{26}$ According to government statistics, by the end of 2003, China's small and medium-sized enterprises accounted for 55.6 percent of the country's GDP, 74.7 percent of industrial production value added, 58.9 percent of retail sales, 46.2 percent of tax revenues, and 62.3 percent of exports. ${ }^{27}$ Nevertheless, SOEs remain the largest enterprises in China, mainly concentrated in important industries, such as electricity, petroleum, railroads, aviation, telecommunications, and banking.

\footnotetext{
24 See State Bureau of Statistics, Report on the Second National Census on Basic Economic Entities (Jan. 17, 2003), http://www.stats.gov.cn/tjgb/jbdwpcgb/ qgjbdwpcgb/t20030117_61467.htm.

${ }^{25}$ See Yingqiu Liu, The General Trends and Problems of China's Private Economic Sectors, J. Chinese ACAd. Soc. SCI., June 2006, http://www.cpes.cass.cn/viewInfo.asp?id=351.

26 Id.

${ }^{27}$ See Non-Public Economy Blooming in China, People's Dally OnLine, July 28, 2004, http://english.people.com.cn/200407/28/eng20040728_151132.html.
} 


\section{B. China's Regulatory Context}

At the same time that China's economic structure underwent fundamental changes, the regulatory structure in China was being transformed to one more compatible with the requirements of a market economy. Before China's economic reforms, China's economic system was modeled after that of the former Soviet Union. For almost every major industry, a corresponding ministry existed within the government to control, manage, and coordinate production. There was no need for government "regulation," as the word is used in Western countries; the industries were already directly owned and managed by the State. But when China began to reduce central direction of its economy after the commencement of its economic reforms, it faced the question of what industries to regulate, and how.

Realizing the problems associated with undue government intervention in the economy, the Chinese government made a strategic choice to retreat from such "non-essential" industries as machinery, electronics, chemicals, and textiles. Those industries do not tend to create conditions of "natural monopoly," do not impinge upon national security and public goods, and usually are not regulated in market economies. In several rounds of government restructuring since 1978, China has gradually dissolved the government ministries overseeing such industries and has replaced them with so-called "chambers of commerce" or "trade associations" representing and coordinating various interests in those industries. ${ }^{28}$

In industries considered key to China's national security and economic development, such as electricity, petroleum, banking, insurance, railroads, and aviation, the Chinese government has chosen to retain or strengthen its dominant role. In those key industries, the major firms remain mostly State-owned. As a result, the government plays two roles: it is both the owner of the major players and the referee, i.e., the regulator. We believe this double role is detrimental to the development of China's market economy. Among the steps that have been taken to address this problem, the foremost has been to establish separate regulatory agencies for the key industries and to strip the SOEs in those industries of the regulatory power given to them in the planned-economy era. In so doing, the Chinese government hopes to separate the government's functions as a producer and as a regulator. For example, between 1998 and 2004, China established the Insurance Regulatory

${ }^{28}$ Leiming Wang, Lutao Shen \& Sheng Zou, Five Comprehensive Government Resiructures 1982-2003, XinhUA News AGENCY, Mar. 6, 2003, http://www.people.com.cn/GB/ shizheng/252/10434/10435/20030306/937651.html. 
Commission, the Banking Regulatory Commission, and the Electric Power Regulatory Commission, which are charged with overseeing the insurance, banking, and electricity industries, respectively. The largest enterprises in those three industries, all State-owned, along with enterprises of other ownership forms that may emerge in the future, are subject to regulation by those new agencies. Furthermore, to strengthen government control of SOEs in key industries and to stop the rapid loss of state assets, China in 2003 established the State Assets Supervision and Management Commission to oversee the operation of State-owned assets.

\section{China's Legal Context}

As China's economy is being transformed from centrally planned to market-oriented, China's legal system is undergoing parallel changes. China's legislature focused on economic laws during most of the past thirty years, most notably laws on contract, bankruptcy, corporations, foreign investment, securities, and the like. The AML is another example of China's efforts to guide economic behavior by reliance on welldefined rules of law.

Although China has enacted many needed economic laws, the enforcement of such laws often is less than satisfactory. Various government agencies charged with implementing the government's regulatory policies have the authority to enforce economic statutes and regulations in their respective areas. Similarly, enforcement of the AML will be carried out by the Anti-monopoly Enforcement Agency, an administrative agency. Enforcement by administrative agencies in China, however, in many cases is not transparent or predictable. First, the rulemaking processes at the administrative agencies are not subject to uniform standards, as China has yet to have a law specifying the procedures administrative agencies are required to follow when making regulations. ${ }^{29}$ Second, under the Administrative Litigation Law enacted in 1989, actions by administrative agencies are subject to judicial review by the People's Courts. The quality of the judicial review provided by the Administrative Litigation Law, however, is quite limited. Among the problems with judicial review of administrative actions most cited by commentators are the narrow scope and convoluted procedures of the review, and the persistent bias in favor of government agencies. ${ }^{30}$

29 Efforts to adopt an administrative procedure law, however, have been underway since 2002.

${ }^{30}$ For more details on China's judicial review of administrative actions, see Chris X. Lin, A Quiet Revolution: An Overview of China's Judicial Reform, 4 AsIan-PaC. L. \& Pol'y J. 9 (2003). 
The People's Courts have problems of their own keeping up with the demands placed on them by China's burgeoning economy. Although the Chinese Constitution states that the People's Courts shall exercise their judicial power independently, in practice there is not much institutional guarantee of judicial independence. Further complicating the matter is the lack of experience of most Chinese judges with complex cases. Until recently, a large portion of Chinese judges were selected from retired military officers. Those judges generally have no formal legal training or experience, and are ill-equipped to handle complicated cases. Although the overall quality of Chinese judges has improved in recent years, it remains doubtful whether Chinese judges-most of whom are not trained in economics or experienced in business-will be competent to handle antitrust cases brought under the AML. Finally, the lack of stare decisis in China will also reduce the effectiveness of judicial interpretation of the AML. China's civil law tradition leaves no place for "judge-made" law. Although the Supreme People's Court has the power to interpret laws as they arise from legal cases, its legal interpretations cannot be cited by other courts and do not serve as precedents as they would in common law countries. This means that potential litigants cannot base expectations of what courts will do under a particular factual circumstance on prior decisions under similar circumstances. Indeed, there is no mechanism for doing so-judges in China generally do not write, much less publish, detailed opinions. Expectations about the behavior of courts are thus difficult to form.

\section{FUNDAMENTAL ISSUES IN THE DRAFTING AND ENFORCEMENT OF THE AML AND CHINA'S BROADER COMPETITION POLICY REFORMS}

The most significant competition policy issues in China are inextricably tied to the fundamental issues arising from China's historic transformation from a centrally planned economy to a market economy. It is those underlying issues, including the role of SOEs, perceived excessive competition, mergers and acquisitions of Chinese companies by foreign investors, administrative monopolies, and the enforcement of the AML, that posed the most significant challenges to China's antitrust policymakers in drafting the AML. How China will enforce the AML in light of those issues will determine the effectiveness of the AML and define the parameters of China's future competition policies.

\section{A. THE Role of SOES}

The primary goal of the AML is to encourage competition. It is the lack of competition in China's economy in general, and in the State- 
owned sectors in particular, that prompted China to start its efforts to enact a comprehensive antitrust law. In recent years, however, China has also sought to strengthen the role of SOEs in certain key sectors. This posed a challenge to China's antitrust policymakers in bringing the SOEs into the framework established by the AML.

Despite the significant progress China had made in other aspects of its economic reforms, by the early 1990s SOEs still accounted for an overwhelming percentage of China's economy. Market entry was tightly controlled by the government in almost every sector. Consumers were left with no meaningful choice but to patronize State-approved SOEs, generating what many consider undeservedly high profits for those 'SOEs. Complaints abounded about the SOEs' abuse of their market power. Perhaps not coincidentally, after China decided to accelerate the market-oriented reforms in 1992, in 1994 it also started the legislating process for its first comprehensive antitrust law.

Since the early 1990s, when China began its efforts to enact a comprehensive antitrust law, it also has implemented various ad hoc measures aimed at introducing more competition into the stagnant sectors controlled by SOEs. The government, as owner of the SOEs, broke up many into multiple entities intended to compete with one another. The restructuring of China's telecommunication industry serves as an example. Before 1994, China's telecommunication industry was monopolized by China Telecom. In 1994, the Chinese government formed China Unicom, a telecommunication provider chartered to compete with China Telecom in mobile phone and pager services. In 1999, China Telecom was broken up into two separate entities: China Mobile provided mobile phone services, and a new China Telecom provided landline services. In the same year, the Chinese government issued landline licenses to several newly formed companies to compete with the newly formed China Telecom. In the next round of restructuring in 2002, China Telecom was further divided and integrated with other telecommunication companies to form two "competing" landline providers: China Netcom based in northern China and China Telecom based in southern China.

While China has reduced the role of SOEs in most economic sectors, the SOEs still exercise very significant, or even increased, control in certain sectors deemed to be of strategic importance to China's economy. Eighty percent of the assets controlled by SOEs in 2006 were concentrated in eight "strategic sectors," such as petroleum and electricity generation. SOEs accounted for almost all of the production of petroleum, natural gas, and ethylene, provided all of the basic telecommunication services, generated approximately 55 percent of electricity, and flew 
about 82 percent of passengers and cargo through the country's air transportation system. ${ }^{31}$

Indeed, at the same time that China was drafting the AML, China also made it a stated goal to maintain the dominant role of SOEs in certain sectors. On December 18, 2006, the State Assets Supervision and Management Commission announced that seven "strategic" industries, including national defense, electrical power generation and grids, petroleum and petrochemicals, telecommunications, coal, civil aviation, and waterway transportation, will be controlled by SOEs. ${ }^{32}$ The government aims to increase State capital in those seven industries and seeks to maintain "absolute control" of them by SOEs. ${ }^{33}$ The State Assets Supervision and Management Commission also announced that it is China's goal to foster thirty to fifty large "internationally competitive" SOEs in those industries by $2010 .{ }^{34}$ In other important industries (but less important than the seven strategic industries), including automobiles, steel, and technology, the government will seek to maintain "somewhat strong influence" by State capital on the leading companies. ${ }^{35}$

China seems to have two contradictory objectives for SOEs. On one hand, it wants to rein in the monopolistic power of SOEs through the adoption of the AML and other reforms; on the other hand, it wants to retain the absolute control of SOEs in certain important sectors. ${ }^{36}$ How to reconcile these two objectives contributed to the prolonged debate on the draft AML. Now that the AML has been enacted, balancing these two objectives in the enforcement of the AML will to a large extent determine the overall effectiveness of the AML.

When deciding on enforcement priorities under the AML, China's antitrust policy makers should consider that maintaining State ownership is not necessarily incompatible with encouraging competition. State

31 See Breaking Up Monopolies Key to the Restructuring of SOEs, LiAOWANG, Dec. 13, 2006, available at http://news.xinhuanet.com/politics/2006-12/13/content_5480196.htm.

32 See State Assets Supervision and Management Commission, Guidance on the Restructuring of State Capital and State Owned Enterprises (Dec. 18, 2006), http://finance. sina.com.cn/g/20061218/11133173443.shtml; see also SOEs to Maintain Overwhelming Control in Seven Sectors, XINHUA NET, Dec. 19, 2006, http://news.xinhuanet.com/fortune/ 2006-12/19/content_5504591.htm.

${ }^{33} \mathrm{Id}$.

34 Id.

$35 \mathrm{Id}$.

${ }^{36}$ In truth, it is not at all clear whether China needs to maintain strong controls by SOEs in what it considers to be strategic or important economic sectors. At least one prominent economist has pointed out that the purpose of such State ownership in those sectors can be accomplished equally well by strict government regulations and strict law enforcement. See Lawrence Lau, The Dual Dilemmas of SOE Reforms, CajJing Magazine, Oct. 31, 2005, http://www.ccmedu.com/bbs2_4724.html. 
ownership of companies in an industry should not be equated with conferring monopoly status on a particular company or a particular group of companies. It is entirely possible to have State ownership of the companies in an industry, and yet to have the State ownership dispersed in dozens, or even hundreds, of SOEs competing against each other and against private firms. ${ }^{37}$ Furthermore, even if China were to decide to grant some type of exclusive status-and thus market power-to the key SOEs in the strategic sectors, such a decision need not be a license for the SOEs to abuse the market power thus granted.

China has already taken steps to introduce more competition into sectors dominated by SOEs. As in the case of the telecommunication industry, China has created more competition among SOEs in certain sectors by breaking up one SOE into multiple entities. In addition, China has taken steps to create more competition between SOEs and private enterprises by allowing private enterprises to enter sectors that were previously off limits. On February 25, 2005, China's State Council promulgated the Opinions on Encouraging, Supporting, and Guiding the Development of Private Capital and Other Non State-Owned Capital (2005 Opinions). ${ }^{38}$ The 2005 Opinions specifically allowed private capital to enter sectors, such as electricity, telecommunications, railroad, civil aviation, petroleum, public utilities, financial services, social services, and national defense. More importantly, the 2005 Opinions allowed market entry by private enterprises as long as such entry is not expressly prohibited by the law, and allowed market entry by domestic private enterprises if foreign investors are allowed such entry.

China's efforts to introduce more competition in sectors previously monopolized by SOEs and to open up more sectors to private enterprises have yielded some successes. In the civil aviation industry, for example, four private airlines have come into operation since $2005 .{ }^{39} \mathrm{In}$ the telecommunications industry, one private company has been allowed to provide call center services. ${ }^{40}$ These successes notwithstanding, China still has a long way to go in terms of promoting competition in

${ }^{37}$ Some argue, however, that SOEs may have stronger incentives to act anticompetitively. See David E.M. Sappington \& J. Gregory Sidak, Competition Law for State-Owned Enterprises, 71 ANTITRUST L.J. 479 (2003). For SOEs to compete efficiently, competition must be an explicit goal of the government as equity owner in the firms.

${ }^{38}$ State Council Doc. No. [2005] 3, Feb. 25, 2005, http://www.china.org.cn/chinese/ PI-c/795128.htm (unofficial Chinese text).

${ }^{39}$ The four private airlines are Aokai Airlines, based in Tianjin; Chunqiu Airlines, based in Shanghai; Yinglian Airlines, based in Chengdu, Sichuan Province; and Dongxing Airlines, based in Wuhan, Hubei Province. Guolu.

40 The private company that was allowed to provide call center services was Dongxing 
the sectors controlled by SOEs. Although some of those sectors have seen an increase in the level of competition, such competition is quite often very limited and consumers still frequently have no alternative to the SOEs. In the telecommunication industry, for example, the two landline providers created by the government in 2002, China Netcom and China Telecom, are based in mutually exclusive territories, and in February 2007 the two companies signed an agreement not to compete for landline customers in each other's territory. ${ }^{41}$ The need for a law like the AML to address such a brazen restriction on competition is obvious.

The AML was enacted against this backdrop. The final AML tries to strike a balance between promoting the dominant status of SOEs in important sectors and subjecting the SOEs in those sectors to the new antitrust regime. The AML states:

In SOE-controlled sectors concerning the health of national economy and national security and in sectors where state trading is authorized by law, the legal operations of the enterprises are protected by law, yet the government will supervise and regulate the prices of the goods and services provided by those enterprises to protect the interests of consumers and promote technology advancement. ${ }^{42}$

The AML further states:

The enterprises referenced in the foregoing clause shall conduct businesses in accordance with law, be honest, exercise strict self-discipline, and be subject to the supervision of the public. Those enterprises shall not hurt the interests of consumers by virtue of their dominant status or state trading status. ${ }^{43}$

While the AML specifically prohibits enterprises in strategic sectorsall of which are SOEs currently-from hurting consumer interests by virtue of their dominant status, it is not clear whether such prohibitions will be vigorously enforced. China may be tempted to be lax on SOEs in order to promote the growth and consolidation of SOEs in key sectors. Such a course of action (or inaction) in our view would have serious negative consequences. In setting enforcement priorities, China's antitrust policy makers need to bear in mind that the behemoth SOEs in monopolized sectors create the most significant distortions in China's economy, and that Chinese consumers would reap immediate benefits

\footnotetext{
41 See China Telecom and China Netcom Reaching Agreement Not to Compete for Landline Customers, BEIJing MoRning Daily, Feb. 27, 2007, http://tech.sina.com.cn/t/2007-02-27/ 01011391578.shtml.

${ }^{42}$ AML, supra note 2, art. 7.

${ }^{43}$ Id.
} 
from enforcing the AML against SOEs. Enforcing the AML against SOEs will also advance China's goal of promoting the long-term growth of SOEs. The current strength of China's SOEs in most sectors is not a result of market competition, but of their monopoly status. Such SOEs will not be able to compete internationally unless they can withstand rigorous market competition. Enforcing the AML against SOEs will provide an important impetus for those SOEs to wean themselves from the protective environment created by their domestic monopoly status. Therefore, the SOEs that currently enjoy monopoly status should be among China's top priorities in the enforcement of the AML.

Finally, although the AML may play an important role in opening up to new competition sectors currently monopolized by SOEs, it alone will not be sufficient for China to achieve that goal. The lack of competition in SOE-controlled sectors is caused by the tight control of market entry by the government. An effective way of promoting competition, therefore, is for the government to liberalize market entry. In addition, since the government is the ultimate owner of the SOEs and could restructure the SOEs as it chooses, the government could effectively promote competition by further breaking up monopolistic SOEs.

\section{B. Perceived Excessive Competition}

In recent years, while China has been trying to curb the monopolistic abuses of SOEs, China's policy makers have simultaneously become concerned about a new threat- "excessive" or "malignant" competition. To many outsiders, this contrast is perplexing, but fear of "excessive competition" is widespread in China. A Google search on the Chinese Internet using the Chinese characters for "excessive competition" yielded approximately one million hits, most of which were press reports of intense competition in various industries. The industries covered by those press reports are diverse, including software, foods, travel agencies, household appliances, telecommunications, maritime shipping, pharmaceuticals, insurance, banking, waste recycling, machinery, mortgage, motor vehicles, periodicals, supermarkets, Internet services, steel, textile and apparels, and even lotteries. The most egregious examples of "malignant competition" reported by the Chinese media were the following:

- China's Central TV network reported in September 2006 that competition in the maritime shipping industry that operates between Shanghai and Japan reached a point where shipping companies incurred losses of $\$ 210$ for each smaller container and $\$ 420$ for a 
larger container. That implies a loss of $\$ 760,000$ per week for an average shipping company. ${ }^{44}$

- In recent years, competition among China's dairy producers has been so intense that many of them resort to illegal means of cutting costs, resulting in scandalous incidents, such as poisonous, recycled, and contaminated milk. ${ }^{45}$

- In China's household appliances industry, there is a widespread practice of libelous advertisement against competitors in the media to gain market share. ${ }^{46}$

- In the travel agency industry, it is not uncommon to have "zero" or even "negative" fees for tours, meaning that many travel agencies are paying customers to take tours with them. ${ }^{47}$

- "Malignant competition" manifests itself not only in China's domestic industries, but also in the country's export sector. In recent years, Chinese products have been the number one targets of antidumping investigations initiated by members of the WTO. Many industry experts and top officials in China blame the excessive competition among China's exporters for this situation. ${ }^{48}$

Needless to say, "excessive competition" has become a major perceived problem in the Chinese economy. Some policy makers believe that most of China's industries, except those in which the government deliberately maintains monopolies by SOEs, are characterized by "excessive competition." 49

Partly because of these perceptions, the government has taken some measures to rein in "excessive competition." Most of those measures involve what is called "industrial self-discipline," adopted under the direct supervision of the government. Under the practice of "industrial self-

\footnotetext{
${ }^{44}$ Malignant Competition Among SOEs in Shanghai's Maritime Shipping Industry, http:// news.tom.com/2006-09-22/0016/78319004.html.

${ }^{45}$ Dairy Companies' Trust Crisis, Economic Reference Newspaper, July 31, 2005, http:// chanye.finance.sina.com.cn/sp/2005-07-13/256435.shtml.

${ }^{46} \mathrm{Ge}$ Ling, Malignant Competition Rampant in China's Household Appliances Industry, PeoPLE's Daily Online, May 11, 2005, http://homea.people.com.cn/GB/41394/ 3379837.html.

${ }^{47}$ Low Price Competition, Malicious Cycle: What China's 10,000 Travel Agencies Should Do? XINHUA NET, Mar. 18, 2005, http://www.ln.xinhuanet.com/wangtan/djjz/lxsdjjz.htm.

48 See, e.g., Long Yongtu: Excessive Competition Among Domestic Companies the Root Cause of Antidumping Cases, June 13, 2005, http://finance.anhuinews.com/system/2005/06/13/ 001282695.shtml.

${ }^{49}$ See Selected Comments on the Draft AML, NPC Standing Committee, June 30, 2006, http://www.npc.gov.cn/zgrdw/common/zw.jsp?label=WXZLK\&id=350218\&pdmc= 110106.
} 
discipline," the major companies in an industry reach price agreements or other agreements to limit competition, in an effort to stabilize the market. ${ }^{50}$ The trade associations that were converted from government ministries played important roles in the adoption of this "industrial selfdiscipline." Indeed, this practice was officially sanctioned by the government in $1998 .{ }^{51}$

Meanwhile, the government has also stepped up its efforts to limit competition among China's exporters to reduce their exposure to antidumping investigations by foreign governments. For instance, in 2003 the government imposed an "advance approval" requirement for the export of thirty-six goods. ${ }^{52}$ Under the requirement, exporters must first submit their export contracts to the respective trade associations for approval prior to export. Policies such as "industrial self-discipline" and "advance approval" to a large degree function simply as governmentsponsored price cartels. However, in implementing those policies, the government apparently was unconcerned about their antitrust implications in domestic markets. ${ }^{53}$

In the face of widespread claims of excessive competition, some of China's policy makers even questioned whether China needs to have an antitrust law when the competition in most sectors of China's economy is already excessive..$^{54}$ To many, China's problem is not that there is too little competition, but that there is too much. What China needs, they believe, is to consolidate the smaller companies into bigger and stronger ones that can compete in the international markets..$^{55}$ The views of those policy makers seem to have been reflected in the AML, where a provision emphasizes that "voluntary" combinations through "fair competi-

${ }^{50}$ For example, faced with growing inventory and price drops, China's nine TV producers held a meeting in southern China in June 2000 to limit TV production and fix prices. The attempted price cartel was not successful, however.

${ }^{51}$ See State Economic and Trade Commission (SETC), Opinions on Self-Disciplinary Prices Adopted by Some Industries, Aug. 17, 1998, http://www.law999.net/law/doc/c001/1998/ $08 / 17 / 00107286$.html. Ironically, before its abolition in the 2003 government restructuring, SETC was one of a few government agencies in charge of drafting the AML.

52 See MOFCOM and Customs Authority Circular 36 of 2003, Advance Approval Requirement for the Export of Thirty-Six Goods, Nov. 29, 2003, http://wwwl.customs.gov.cn/ Default.aspx?TabID=433\&InfoID=11070\&:SettingModuleID=1427.

${ }^{53}$ The antitrust problems associated with those competition-limiting policies were perhaps first brought to the attention of the Chinese policy makers by three antitrust lawsuits filed in the United States in 2005 and 2006 alleging price fixing by Chinese exporters of Vitamin $\mathrm{C}$, magnesite, and bauxite.

54 See Selected Comments on the Draft AML, supra note 49.

${ }^{55}$ See, e.g., id., Comments by Mr. Zheng Gongcheng. 
tion" to "expand operation scale and improve competitiveness in the market" will be allowed. ${ }^{56}$

China's concerns with perceived excessive competition are also reflected in several provisions in the AML dealing with trade associations. As discussed above, China's policymakers see a positive role of the government-agencies-turned-trade associations in regulating market order. There is a risk, however, that the trade associations may cross the line and impose undue restrictions on competition or, in some cases, function as outright price cartels. The final version of the AML seeks to strike a balance between allowing legitimate activities of the trade associations and limiting the anticompetitive aspects of those activities. In one provision, the AML states that "trade associations shall strengthen industrial self-discipline and channel enterprises in their respective industries into lawful competition, in order to maintain the order of market competition." ${ }^{57}$ In another provision, the AML states that "trade associations shall not organize enterprises in their industries to engage in monopolistic activities prohibited under this Chapter [Monopolistic Agreements]." 58

Despite these signs of compromise between promoting competition and ensuring market stability, it is clear that the balance in the AML is slightly tilted towards the latter. Nowhere is this bias more vividly displayed than in the exceptions to monopolistic agreements written into the AML. After laying out a general prohibition of monopolistic agreements, the AML enumerates several types of agreements that will be exempted from the prohibition. The exempted agreements not only cover agreements for purposes of product standardization and environmental protection, but also include "agreements reached during economic recessions for purposes of alleviating declines in sales volumes or production over-capacity," as well as "agreements reached for purposes of protecting the legitimate interests of international trade and foreign economic cooperation." 59

Despite claims of widespread excessive competition and its destabilizing effects, it is important that China should not let the bias in favor of market stabilization evident in the text of the AML tie the hands of

${ }^{56}$ AML, supra note 2, art. 5 ("Enterprises may voluntarily consolidate and conduct lawful combinations through fair competition to expand business scopes and increase competitiveness."). See also The Draft AML Both Prevents Monopolies and Allows Bigger and Stronger Enterprises, XINHUA News Net, June 24, 2007, http://news.xinhuanet.com/legal/2007-06/ 24/content_6284628.htm.

${ }^{57}$ AML, supra note 2, art. 11.

${ }^{58} \mathrm{Id}$. art. 16.

${ }^{59}$ Id. art. 15. 
the antitrust regulators in the enforcement of the law. First, the term "excessive competition" as it is understood in China is a misnomer. Most examples of claimed excessive competition found in China's economy are not examples of there being too much competition; rather, they are examples of competition going awry. Common to almost all is the fact that the competitors have engaged in illegal, or even criminal, acts that violate the existing competition laws, product safety laws, and consumer protection laws or would have violated the AML were it in effect. The fact that such practices are widespread in China only underscores, rather than detracts from, China's need to strictly enforce the existing laws and the AML. Only through effective enforcement of such laws can competition deliver maximum benefits to consumers.

Second, to the extent that the claimed excessive competition does signify an abundance of lawful competition, it should be welcomed, not restricted. Competition itself should always be welcomed, especially when it is not good for competitors. Competition of the kind the antitrust law is intended to promote can never be "excessive." The experience of the United States during the Great Depression provides a valuable lesson. During the Great Depression it was widely believed in the United States that "excessive" competition was responsible for deflationary price pressures and unemployment. The Roosevelt administration made various attempts to limit price competition. These policies are now seen as unsound-they harmed consumers and probably prolonged the Great Depression, which was not caused by "excessive" competition. The U.S. Supreme Court during the Great Depression also wavered on whether the antitrust laws should be strictly enforced when increasing competition and falling prices were causing widespread distresses in the economy in the famous case of Appalachian Coals, Inc. $v$. United States. ${ }^{60}$ Fortunately, the Court eventually reversed its course. ${ }^{61}$ As noted above, Article 15 of the AML exempts agreements among competitors to alleviate declines in sales volumes and production over-capac-

60288 U.S. 344 (1933). Similarly, as noted above, Article 15 of the AML exempts agreements among competitors to alleviate declines in sales volumes and production over-capacity during economic downturns. See id.

${ }^{61}$ The U.S. practice had been to treat price-fixing agreements as per se illegal under the Sherman Act. In Appalachian Coals, however, the U.S. Supreme Court held that the creation of an exclusive joint selling agency by 137 Appalachian producers of bituminous coal was reasonable and therefore did not violate the Sherman Act. In so holding, the U.S. Supreme Court was greatly influenced by the dismal conditions in the industry caused by the Great Depression. Seven years later, however, the U.S. Supreme Court reversed course. In United States v. Socony-Vacuum Oil Co., 310 U.S. 150 (1940), the Supreme Court rejected the approach it took in Appalachian Coals, and unequivocally reaffirmed the per se rule for horizontal price fixing. 
ity during economic downturns, revisiting the erroneous economics of Appalachian Coals.

In sum, although claims of excessive competition have prolonged the debate on the drafts of the AML and the AML includes compromises to accommodate the views of those arguing for market stability over competition, China should not let the concerns about market stability cripple the enforcement of the AML. Instead, China should make it a top priority to ensure a high level of competition.

\section{Mergers and Acquisitions of Chinese Companies by Foreign COMPANIES}

A major goal of the AML is to deal with foreign investors acquiring Chinese companies through mergers and acquisitions. Foreign investors have played an important role in China's economic revival since the very beginning of China's economic reforms almost three decades ago. Upon China's accession to the World Trade Organization (WTO) in 2001, China agreed to reduce tariff levels drastically and made numerous market access commitments regarding a number of industries. In the years following China's WTO accession, foreign companies increasingly steered their investment in China towards acquiring local Chinese companies. An increasing number of mergers and acquisitions by foreign companies heightened China's concerns that its industries might be dominated, or even controlled, by foreign companies.

In response, China imposed many ad hoc limitations on mergers and acquisitions by foreign companies. A prominent example is the recent intervention by the government in the acquisition by the U.S. private equity firm Carlyle Group of Xugong Construction Machinery, China's leading manufacturer of heavy construction equipment. It was reported that Carlyle Group initially signed an agreement in October 2005 to buy 85 percent of Xugong's shares. The deal was fiercely opposed by government officials, however, as well as by Xugong's rivals. About one year later, Carlyle Group agreed to take a less than 50 percent stake in Xugong in exchange for the government approval of the acquisition. ${ }^{62}$

The ad hoc limitations imposed on mergers and acquisitions by foreign companies are part of China's broader efforts to scale back foreign investment in certain sensitive sectors. Although China has more or less fulfilled its market access commitments since its accession to the WTO, it has also revoked some of the preferential treatments previously ac-

62 See Carlyle Agrees to Hold Minority of Xugong's Shares, SoHu Bus. Onulne, Oct. 17, 2006, http://business.sohu.com/20061017/n245845506.shtml. 
corded to foreign investors and, in some cases, has put in place some new restrictions. ${ }^{63}$ Coincidentally or not, the flow of foreign investment into China has shown signs of leveling off in recent years. ${ }^{64}$

China may be tempted to use competition policy as an additional tool to achieve its goal of limiting foreign investment in certain sectors. The promulgation of the 2006 M\&A Rules is seen by many as the first step in that direction. When drafts of the AML were being discussed, many multinational corporations feared that they would become the law's first targets. ${ }^{65}$ This fear was reinforced when a Chinese court in early 2007 decided to hear antitrust claims filed by a local Chinese company against a prominent multinational company. ${ }^{66}$ Although the final text of the AML does not single out foreign companies, except in a provision requiring "national security review" in mergers and acquisitions of domestic companies by foreign companies, ${ }^{67}$ there is a risk that the AML will primarily target foreign companies. Unlike all of the controversial topics surrounding the debates on the AML, the necessity of limiting entry by foreign companies in key sectors is one of the few concepts on which China's policymakers have a near consensus. The United States has similar concerns, limiting foreign ownership of broadcast stations, airlines, and merchant vessels.

China's antitrust regulators should guard against the risk of singling out foreign companies in enforcing the AML. Although China may be rightly concerned about possible aggressive campaigns by behemoth multinational corporations to monopolize Chinese domestic markets, it

${ }^{63}$ For example, on March 16, 2007, China's National People's Congress adopted the amended Corporate Income Tax Law that would abolish the preferential corporate tax treatment currently enjoyed by foreign-invested companies. In December 2005, China's Securities Regulatory Commission imposed a moratorium on new foreign investment in Chinese securities brokerages. In August 2006, China's Banking Regulatory Commission announced a requirement that foreign banks incorporate their local operations in China if they want to engage in RMB-denominated business with Chinese individuals. While these restrictions technically do not violate China's WTO commitment, and some indeed may be well justified, foreign investors have criticized them as steps in the wrong direction. See Statement of John R. Dearie, Testimony Before the U.S.-China Economic Security Review Commission (Aug. 22, 2006), http://www.uscc.gov/hearings/2006hearings/ written_testimonies/06_08_22_23wrts/06_08_22_23_dearie_john.php.

${ }^{64}$ In 2006, China saw a 4 percent decrease in foreign investment compared with the year before. See Ariana Eunjung Cha, China Gets Cold Feet for Foreign Investment: New Regulations Spawn Fears of Economic Nationalism, WASH. Post, Feb. 2, 2007, at D1.

${ }^{65}$ See Rebecca Buchman, China Hurries Antitrust Law, Wall St. J., June 11, 2004, at A7.

${ }_{66}$ On January 17, 2007, The Shanghai No. 1 Intermediate People's Court heard claims by a local Chinese company that Sony and its joint venture in China engaged in unfair competition by designing their digital cameras to shut down when batteries made by competitors are installed. The court did not rule at the end of the hearing and the case is still pending.

${ }^{67}$ See AML, supra note 2, art. 31. 
would be a grave mistake to allocate most resources to fighting foreigncontrolled monopolies when such monopolies are not a major threat. ${ }^{68}$ The losses to consumer welfare caused by the anticompetitive acts of domestic companies are no less real than the losses to consumer welfare caused by the anticompetitive acts of foreign companies, and indeed, the degree of monopolization by foreign companies-often exaggerated in the Chinese media-is far less than the degree of monopolization in the industries controlled by SOEs. To focus the AML on foreign companies, or to enforce strictly the AML only against foreign companies, would lead to missed opportunities to address a major source of distortion in China's economy.

\section{Administrative Monopolies}

One of the most important features of the AML is the devotion of an entire chapter to the issue of "administrative monopolies." The AML does not give a definition of administrative monopoly. But, as suggested by the name, administrative monopolies are monopolies created by administrative agencies. Chapter Five of the AML sets forth the general principles dealing with governmental actions that have the intent or effect of creating monopolistic conditions. It specifically lists several categories of governmental actions that would be prohibited: mandated use of products and services, regional blockades, restrictions on bidding, restrictions on market entry, and restrictions on competition. ${ }^{69}$

The inclusion of the prohibition of administrative monopolies in the AML has a tortuous history. The prohibition appeared in the first several drafts released for comments beginning in 2002. It was reported, however, that in December 2005 the State Council deleted the entire chapter of the draft law dealing with administrative monopolies from an internal draft and only kept a declaratory statement prohibiting administrative monopolies in principle in the general rules section. ${ }^{70}$ In June 2006, the State Council officially approved a draft that did not contain the chapter on administrative monopolies. ${ }^{71}$ But several weeks later,

${ }^{68}$ According to a government report released in September 2007, China does not face an imminent risk of monopolies by foreign companies in any industry. See Jiang Wei, No Threat of Foreign Monopoly in Any Industry, China Daily OnLINe, Sept. 10, 2007, http:// www.chinadaily.com.cn/bizchina/2007-09/10/content_6092857.htm.

${ }^{69}$ See AML, supra note 2, arts. 32-37.

${ }^{70}$ See Xiaodong Xie, Anti-Administrative Monopolies Chapter Deleted in Entirety from Draft Antimonopoly Law, People's Daily Online, Jan. 11, 2006, http://www.people.com.cn/GB/ 54816/54822/4016799.html.

${ }^{71}$ See State Council Approves Draft Antimonopoly Law Without Chapter on Administrative Monopolies, People's Daily Online, June 8, 2006, http://finance.people.com.cn/GB/1037/ 4448654.html. 
when the State Council submitted the draft law to the NPC Standing Committee for its first reading, the chapter on administrative monopolies had been reinserted. ${ }^{72}$ These unusual changes in the text of the draft law reflect what perhaps was the biggest dilemma facing China's antitrust policy makers-i.e., whether China should include provisions prohibiting administrative monopolies in the new antitrust law.

The reason why the issue of administrative monopolies is so central to the AML is because of the ubiquity of such monopolies in China. Administrative monopolies manifest themselves in many kinds of governmental actions. First, administrative monopolies result from governmental measures that are intended to restrict competition in a particular industry or from governmental measures that compel certain anticompetitive conduct. For example, in 1999, China's Bureau of Civil Aviation issued an order prohibiting airlines from offering air ticket discounts, citing the adverse effect of price competition on the healthy development of the airline industry. ${ }^{73}$

Second, administrative monopolies also result from governmental measures that mandate the use of products or services by certain producers that usually are "affiliate companies" of the government agencies. Those affiliate companies are in most cases SOEs or former SOEs currently or previously controlled by the government agencies in question. A good example of this practice is that some local civil affairs agencies in charge of issuing marriage licenses require applicants to take pictures to be affixed to marriage licenses only at designated photo studios. Such steering of business towards affiliated companies using government power is declared illegal under Article 32 of the AML.

Third and most important, administrative monopolies also result from governmental actions that restrict market entry. This problem is more serious at the local level, where the local governments are notoriously known for creating various barriers to firms from other localities. This local protectionism is what is commonly known as "regional blockage" and is declared illegal under Article 33 of the AML.

Each of the three variants of administrative monopolies is made possible by the ability of governmental agencies, at both the central and local levels, and with or without statutory authority, to require government approvals for a wide range of economic activities. According to a survey

\footnotetext{
72 See Na Liu, Draft Antimonopoly Law on Schedule for Review; Chapter on Administrative Monopolies Added Back In, ECON. ObSERver, June 25, 2006, http://info.finance.hc360. com/2006/06/25102650097.shtml.

${ }^{73}$ However, the ban on discount air tickets was frequently ignored by the airlines, and the ban was finally lifted in early 2003 .
} 
conducted by the State Council, in 2003 there were a total of 4,159 projects in which approvals of some sort from various governmental agencies were required, and more than 2,000 approval requirements were implemented without any legal basis. ${ }^{74}$ To make things worse, in many cases businesses have to navigate through the maze of those approval requirements without clear guidance from the governmental agencies.

The following statistics provide a clue to the seriousness of the problem of administrative monopolies in China. It is reported that from 1995 to 2004, the SAIC investigated 5,642 cases of monopolies pursuant to the Anti-Unfair Competition Law, 519 of which were administrative monopolies. ${ }^{75}$ The same report stated that since its establishment in 2003, MOFCOM has reviewed 432,841 policies of local governments that allegedly contained elements of regional blockades, pursuant to the 2001 Rules on Prohibiting Regional Blockades in Market Economic Activities. Of those 432,841 policies, 301 were modified or annulled by MOFCOM. ${ }^{76}$ On the face of these statistics, it may seem that administrative monopolies constitute only an insignificant part of the total cases being investigated or reviewed. The source of the statistics, however, observed that this is a result of selection bias, as the government authorities were reluctant to investigate or confront administrative monopolies because of what they saw as the futility of such actions. ${ }^{77}$

When drafting the AML, China's antitrust policymakers faced real challenges on whether-and how-to bring administrative monopolies into the new framework. On one hand, as the ubiquity of administrative monopolies has made them the major source of monopolies in China's economy, China's antitrust policy makers felt obliged to address them in the AML. Many commentators believed that without provisions prohibiting administrative monopolies, the AML would necessarily be incomplete and would lose much of its relevance. ${ }^{78}$ Furthermore, without a prohibition of administrative monopolies, the public may believe that the government does not have the resolve to fight monopolies at all and may discount the credibility of the other provisions of the law.

\footnotetext{
74 See Jianjun Wang, Special Interests the Greatest Obstacle to Market Development, Liaowang News WKLY, Dec. 13, 2006, http://news.sohu.com/20061213/n247014585_1.shtml.

${ }^{75}$ See Anti-Administrative Monopolies Chapter Deleted in Entirety from the AML, PEople's Daily Online, Jan. 11, 2006, http://www.people.com.cn/GB/54816/54822/4016799. html.

${ }^{76} I d$.

${ }^{77} \mathrm{Id}$.

${ }^{78}$ See, e.g., Ya Jie, Antimonopoly Law Must Address Administrative Monopolies, ChInA Indus. \& Bus. Times, Apr. 19, 2006, available at http://biz.163.com/06/0419/10/2F2JT1NE0002 1RH4.html.
} 
On the other hand, prohibiting administrative monopolies in the AML may not yield many successes in the near future, given China's current economic and political realities. Fighting administrative monopolies means taking on local governments, a task that even China's political system is not ready to handle, let alone China's legal system. Throughout the history of China, there has been the so-called "central versus local governments" problem, i.e., the problem of enforcing the orders and policies of the central government at the local level. ${ }^{79}$ "The mountain is high and the Emperor is far away." "Where there are policies from above, there are counter-policies from below." These old Chinese sayings speak vividly to the troubled relationship between the central and local governments. It is unlikely that China will be able to use the AML to address local protectionism and "regional blockade" and yet avoid this 3,000-year-old obstacle. Even for administrative monopolies created by the ministries of the central government, the ability of the AML to force meaningful changes in the way the central government conducts its business will be very limited, not least because China's government system is still largely based on fiat, not rules of law.

Despite these challenges, the prohibition of administrative monopolies is now in the final draft of the AML. Along with the SOEs in monopolized sectors, China's government agencies at various levels create most of the restrictions on competition in China's economy, and the popular appeal for taking on administrative monopolies under the AML is enormous. ${ }^{80}$

While the AML prohibits administrative monopolies, it also makes a compromise that casts the effectiveness of the prohibition in doubt. In a provision dealing with the legal liabilities for violating the prohibition of administrative monopolies, the AML states:

79 The relationship between the central and local governments has been problematic since the Zhou Dynasty (1122 B.C.-225 B.C.) and remains so today. One of the most dramatic episodes of the "central versus local governments" problem is the civil war waged by Emperor Kangxi of the Qing Dynasty in the 1670s against three feudal lords, who were granted their fiefdoms as rewards for their contributions to the establishment of the Qing Dynasty but who later grew defiant of the orders of the Emperor. The war, spanning eight years and spreading to almost half of China's territory at the time, ended with a complete victory for the Emperor.

${ }^{80}$ China's antitrust rules prior to the AML already contained some variants of the prohibition of administrative monopolies. For instance, Article 30 of the 1993 Anti-Unfair Competition Law prohibits restrictions on competition by using administrative power (supra note 3), and the 2001 Rules on Prohibiting Regional Blockades in Market Economic Activities specifically bans regional blockades (supra note 9). Therefore, including the prohibition of administrative monopolies in the AML preserves continuity in the treatment of administrative monopolies. 
If government agencies and other organizations that are authorized by law to possess the authority to regulate public affairs abuse their administrative power and engage in activities that exclude or restrict competition, such activities shall be ordered to be corrected by the relevant superior government agencies. The officials and other personnel who are directly responsible for such activities shall be punished by law. The Anti-monopoly Enforcement Agency shall provide the superior government agencies with advice as to how such officials or personnel should be published by law. ${ }^{81}$

It is clear from this provision that the enforcement of the prohibition of administrative monopolies will be carried out by the superior government agencies through fiats, not by the Anti-Monopoly Enforcement Agency. The Anti-Monopoly Enforcement Agency is only to play an advisory role. This arrangement is a reluctant acknowledgement of the fact that tackling administrative monopolies through the legal system in China is still not feasible at this time.

Notwithstanding the inability of the Anti-monopoly Enforcement Agency to enforce the AML against administrative monopolies, China needs to actively pursue other reforms necessary to control administrative monopolies. Otherwise, the most significant restrictions on competition in China's economy would be left intact. China's policy makers need to bear in mind that the antitrust law is not the sole, or even the most important, vehicle through which to address administrative monopolies. ${ }^{82}$ The nature of administrative monopolies means that their elimination will necessarily require other reforms, such as changes in constitutional and government structure reforms. Indeed, in most developed countries, such as in the United States, administrative monopolies are dealt with in the general antitrust law only to the extent that they are a result of the action of the State as market participant. In dealing with monopolistic conditions created by the State as sovereign and market regulator, the United States generally leaves the job to the democratic legislative processes at both the federal and state levels, while using certain important legal mechanisms-such as the "Dormant Commerce

${ }^{81}$ AML, supra note 2, art. 51 (emphasis added).

82 It seems that China's antitrust policy makers are well aware of this point. An earlier draft AML, released in June 2006, points out that the furtherance of reforms of the government functions are needed to rein in the abuse of administrative power that harms competition. 
Clause"83 and the federalism doctrine ${ }^{84}$-to correct any failures of the democratic processes in this regard. China needs to push forward with constitutional and government structure reforms that address the root cause of administrative monopolies.

\section{E. ENForCement of the AML}

An important consideration in drafting any law in any country is how the law is to be enforced. All the more so in China, where enforcement of a law in many cases is a larger issue than the law itself. Debate on the enforcement of the AML contributed to the AML's prolonged drafting process. The effectiveness of the AML will in large part depend on setting appropriate enforcement priorities and establishing correct and clear expectations on the part of business entities.

\section{Which Agency?}

Prior to the AML, the responsibility for enforcing China's antitrust rules is shared by three agencies: the SAIC as authorized by the 1993 Anti-Unfair Competition Law, the National Development and Reform

88 The U.S. Constitution grants Congress the power to regulate interstate commerce in the so-called Commerce Clause. By negative implication, the U.S. Supreme Court holds that states do not have the power to regulate interstate commerce. This so-called Dormant Commerce Clause doctrine played a vital role in striking down state regulations that were aimed at or had the effect of blockading the commerce of other states. See, e.g., Granholm v. Heald, 544 U.S. 460 (2005) (ruling that New York and Michigan laws allowing in-state wineries to ship wine to consumers directly but prohibiting out-of-state wineries from doing the same is unconstitutional); Philadelphia v. New Jersey, 437 U.S. 617 (1978) (invalidating a New Jersey law that prohibited the importation of most solid or liquid waste which originated or was collected outside of the territorial limits of New Jersey); Baldwin v. G.A.F. Seelig, Inc., 294 U.S. 511 (1935) (holding that New York may not protect its local interests by limiting access to local markets by out-of-state milk sellers); Gibbons v. Ogden, 22 U.S. 1 (1824) (invalidating New York's grant of steamboat monopoly).

${ }^{84}$ Under the federalism doctrine, the U.S. federal government can only exercise power granted by the U.S. Constitution. The U.S. Supreme Court has used the federalism doctrine to invalidate federal laws that had the purpose or effect of limiting competition. Most notably, in 1935, in the "sick chicken" case, the U.S. Supreme Court stuck down one of the most dramatic efforts by the Roosevelt administration to stabilize the U.S. economy during the Great Depression-the National Industrial Recovery Act of 1933 (NIRA). See Schechter Poultry Corp. v. United States, 295 U.S. 495 (1935). Enacted to combat falling prices and intensifying competition during the Great Depression, the NIRA authorized the President, ordinarily upon application by trade associations, to promulgate "codes of fair competition" for the trade or industry. Several hundred codes were adopted in accordance with the NIRA. The codes usually contained provisions concerning minimum wages and prices, maximum hours, and unfair trade practices. In 1935, the Supreme Court struck down the entire Act, holding that in enacting the Act, Congress exceeded its commerce power and unconstitutionally delegated its legislative power. Interestingly, there seems to be a striking resemblance between the "codes of fair competition" authorized under the NIRA and the "industrial self-discipline" authorized by the Chinese government today. See discussion of the "industrial self-discipline," infra Part IV.B. 
Commission as authorized by the 2003 Provisional Rules on Prevention of Monopoly Pricing, and MOFCOM as authorized by the 2006 M\&A Rules. Earlier drafts of the AML proposed the establishment of an AntiMonopoly Enforcement Agency under the State Council to enforce the future AML. There was speculation that the Anti-Monopoly Enforcement Agency would be created within an existing ministry. Given the prominent roles SAIC and MOFCOM played in enforcing the pre-existing antitrust rules, these two agencies naturally became the leading candidates to house the future Anti-Monopoly Enforcement Agency.

SAIC is primarily charged with the micromanagement of market activities, ranging from business and trademark registration to street market regulation. SAIC has branches in virtually every city in China. At the central level, SAIC has a Bureau of Fair Trade, under which there is an Anti-monopoly Division. However, this division has only five staff members. ${ }^{85}$ In March 2004, SAIC released an investigative report that described multinational companies' alleged anticompetitive behavior in China. ${ }^{86}$

The other candidate is MOFCOM, a powerful ministry created during the government restructuring in 2003 that combined the former Ministry of Foreign Trade and Economic Cooperation and many functions of the former SETC. MOFCOM in late 2004 established an Anti-Monopoly Investigation Office under the Department of Treaty and Law. ${ }^{87}$ This office now has about the same level of staffing as its counterpart in SAIC. Both agencies at MOFCOM and SAIC were designated to review foreign acquisitions of domestic companies under the $2006 \mathrm{M} \& \mathrm{~A}$ Rules $^{88}$ However, the Antitrust Filing Guidelines accompanying the M\&A Rules were issued by MOFCOM alone.

The AML eventually settled on a two-layer enforcement regime. The law requires the establishment of an Anti-Monopoly Commission under the State Council, whose functions include competition policy making, issuance of investigative reports and assessments on market competition, issuance of antitrust guidelines, and coordination of the enforcement of the AML. ${ }^{89}$ It seems that the Anti-Monopoly Commission is intended to

${ }^{85}$ See SAIC, Functions, Organization, and Staffing of the Bureau of Fair Trade, based on information shown on Sept. 16, 2006, http://www.saic.gov.cn/zhzjg/jig_3.html.

${ }^{86}$ See SAIC, Multinational Companies' Competition Restricting Behavior and Counter Measures, SAIC Pub. No. 5 (2004).

${ }^{87}$ See MOFCOM Establishes Antimonopoly Investigation Office, CHINA NEws NeT, Sept. 17, 2004, http://www.china.org.cn/chinese/2004/Sep/661853.htm. Noticeably, this was a few months after the release of the SAIC report on multinational companies.

${ }^{88}$ See Rules on Acquisition of Domestic Enterprises by Foreign Investors, supra note 12.

${ }^{89}$ AML, supra note 2 , art. 9 . 
be an inter-agency coordinative body on antitrust policy making. The day-to-day enforcement of the AML will be carried out by the Anti-Monopoly Enforcement Agency. ${ }^{90}$

An early 2004 draft of the AML proposed to establish the Anti-Monopoly Enforcement Agency under MOFCOM, but later drafts retreated from that position. The final AML states only that an Anti-Monopoly Enforcement Agency will be "designated" by the State Council, without specifying where. ${ }^{91}$ This arrangement is a postponement of the decision on the Anti-Monopoly Enforcement Agency in order to secure faster enactment of the AML. Now the State Council could designate a completely new agency, or designate an agency sitting within an existing ministry; either would be consistent with the language of the AML.

It would be in China's best interest to elect the first option, i.e., establishing an independent Anti-Monopoly Enforcement Agency that is not subjugated to any existing ministry. This effectively means creating a new agency under the State Council at the ministry level. The justifications for establishing such a high-level agency are twofold. First, the Anti-Monopoly Enforcement Agency must possess enough independence and authority to carry out its statutory functions. Although the Anti-Monopoly Enforcement Agency is relieved of the duty to bring enforcement actions against other ministries or local governments for violations of the prohibition of administrative monopolies, it still needs to take actions against SOEs in monopolized sectors, a task not much easier politically. For historical reasons, many, if not all, of the SOEs in monopolized sectors are protégés of certain ministries. Taking on those SOEs would essentially mean taking on the ministries behind them. In enforcing the AML against those SOEs, the Anti-Monopoly Enforcement Agency must not be influenced by other ministries and must possess the authority necessary to carry out its duties. Such independence and authority can only be guaranteed by having a new agency at a very high level-meaning the ministry level. Second, the Anti-Monopoly Enforcement Agency would require an enormous amount of resources, given the size of China's economy and the amount of anticompetitive activities in the marketplace. Placing the Anti-Monopoly Enforcement Agency under an existing ministry would force the Anti-Monopoly Enforcement Authority to compete for resources allocated to the ministry in which it sits and could seriously limit its performance. Indeed,

90 Id. art. 10 ("The agency designated by the State Council as the agency responsible for antimonopoly enforcement (hereinafter "Anti-Monopoly Enforcement Agency") shall be responsible for anti-monopoly enforcement under this law.").

${ }^{91}$ Id. 
neither of the anti-monopoly offices established under MOFCOM and SAIC so far seems to have enough manpower or resources to handle the potentially vast amount of work required to enforce the AML.

\section{Which Enforcement Priorities?}

Given the limited institutional capability and resources at least at the initial stage, China's future Anti-Monopoly Enforcement Agency will need to set priorities for its enforcement goals. A good start is to focus, first, on horizontal restraints of trade, especially cases of price fixing and bid rigging, where large benefits can often be obtained for consumers by breaking up cartels and introducing competition. Enforcement in this area has high payoffs because it is likely to deter behavior that harms consumers and unlikely to erroneously deter competitive behavior that benefits consumers.

In countries with new competition policies, there is often a tendency to focus on complex vertical relationships because of complaints about these matters filed by competitors, and on consumer protection issues because of popular appeal. Often, certain contracts or contractual terms, or pricing schemes in general, may strike people as unfair, even if they actually promote economic efficiency. Examples include vertical price restraints, ${ }^{92}$ "unfairly high price in selling or unfairly low price in purchasing," "selling goods at below-cost prices for no reasonable reasons," unilateral refusals to deal, exclusive dealerships, certain tying arrangements, and price discrimination..$^{93}$ In societies that are skeptical of the legitimacy of markets, enforcement focusing on these issues often illustrates the popular or ideological basis for the skepticism. Antitrust action in these areas requires painstaking investigation and analysis, not merely to decide whether the behavior in question is harmful or beneficial to consumers, but also to avoid creating unintended deterrent effects on future economic activity that is beneficial to consumers. In general, it is important to resist the temptation to give priority to investigations that consume a vast amount of resources but have minimal benefits.

Although the antitrust review of proposed mergers, acquisitions, and joint ventures is a very useful device to avoid anticompetitive concentration (without the messy complication of ex post disassembly of a consummated transaction), the amount of work involved can easily be overwhelming. Unfortunately, the AML applies to all consolidations that meet the sales thresholds rather than just consolidations of competing

92 See id. art. 14.

${ }^{93}$ See id. art. 17. 
firms. The effect could be to unnecessarily burden the Anti-monopoly Enforcement Agency and increase the delays associated with obtaining agency clearance for mergers with little or no potential for anticompetitive effects, including many beneficial mergers. It is important for the Anti-Monopoly Enforcement Agency to give quick clearance to mergers that do not pose a competition issue and focus on those that have clear overlaps. This implies the need for a limit on the amount of time transactions are held up pending agency decisions on enforcement.

\section{The Importance of Transparency and Consistency}

For the AML to influence business behavior in the intended way, businesses need to form both correct and clear expectations about its enforcement. To allow business to establish such expectations, they must be informed of the enforcement decisions of the Anti-Monopoly Enforcement Agency. In addition, it is also necessary to have a rule that plays the role of stare decisis in a common law system. That is, the AntiMonopoly Enforcement Agency must to some extent be bound by its prior decisions and reasoning. If administrative agencies can decide each case without regard to the ways in which similar facts have been analyzed and treated in the recent past, businesses will have no basis to form expectations about the consequences of their actions. The effect of this is to increase the risks of doing business, thus discouraging investment by ruling out investment projects that do not have a sufficiently high expected return to compensate investors for taking on the risk of (erroneous) antitrust prosecution.

The requirement to publish enforcement decisions would be a good first step to implement the AML in a transparent and consistent way. In earlier drafts of the AML, the Anti-Monopoly Enforcement Agency was required to publish decisions. In the final version of the AML, however, the language was changed from "must publish" to "may publish." 94 This change seems to reflect a reluctance of the Chinese authorities to commit to full disclosure of the Anti-Monopoly Enforcement Agency's future antitrust decisions, which is not helpful for businesses attempting to form expectations about the Anti-Monopoly Enforcement Agency's actions. This retreat from transparency and consistency may reflect the likelihood that the Anti-Monopoly Enforcement Agency may take into account non-competition factors, such as the public interest and the health of the national economy, in deciding competition cases. But here as well, making the enforcement agency responsible for such broad considerations would be a mistake. The agency's decisions will be subject to

94 See id. art. 44. 
political review, and it is in that review process that such considerations may enter.

More generally, unless antitrust enforcers are to attempt to examine every transaction in the economy, deterrence is the principal vector by which antitrust (and most other) laws achieve their effects on economic behavior. Deterrence of anticompetitive behavior, however, has a dark side: inadvertent deterrence of efficient behavior. The deterrent effect of a law or regulation is affected by the probability of detection and successful prosecution (itself a function of enforcement resources), the firm's understanding of the law, and the penalties expected to result from successful prosecution. Very effective deterrence of anticompetitive behavior will also deter procompetitive behavior if the law is unclear to private decision makers or if private decision makers anticipate frequent errors by prosecutors and judges. ${ }^{95}$ Thus, transparency and consistency in enforcement are important in helping businesses form expectations consistent with the intent of the law.

The AML gives private parties the right to judicial review if they are not satisfied with the Anti-Monopoly Enforcement Agency's decisions. In the context of China's current legal system, it remains unclear whether this right will increase the predictability of the process. As discussed in Part III.C, in general, the courts' ability to adjudicate antitrust cases is doubtful at this time, as they do not seem to have the necessary expertise. China's policymakers are aware of the inadequate capacity of the courts in adjudicating antitrust cases under the AML. In some earlier drafts, civil liabilities and recovery of damages through litigation were emphasized. One draft even suggested a detailed methodology of computing damages. Later drafts, however, minimized direct mention of the courts' role. Apparently there is reluctance to rely on the judicial system to handle antitrust cases.

The AML clearly contemplates reliance on the administrative, rather than judicial, system as its primary enforcement mechanism. It is expected that China will issue detailed rules and regulations to implement the AML before it takes effect on August 1, 2008. In the end, given China's legal environment, as noted above, it is these rules and their enforcement that will matter most. It would be inappropriate to evaluate the AML as if it were a set of instructions intended for the judiciary to interpret. To the extent that administrative agencies are more competent in carrying out the enforcement of the AML, it makes sense, at least

95 See generally Ken Heyer, A World of Uncertainty: Economics and the Globalization of Antitrust, 72 ANrrTrRust L.J. 375 (2005). 
in the short term, to rely more on administrative decisions and remedies.

\section{CONCLUSION}

China has come a long way since drafting of the AML began in 1994. Compared with China's prior antitrust laws and regulations, the final draft of the AML makes significant progress in terms of comprehensiveness, clarity, and consistency with economic principles. Despite the progress, however, China's antitrust policy makers still face significant challenges in enforcing the AML and reforming the country's competition policies.

In enforcing the AML, China's antitrust regulators would do well to focus on SOEs in monopolized sectors and need not be overly concerned about the claimed excessive competition. China's antitrust regulators should also guard against the temptation to enforce the AML vigorously only against foreign companies. To guarantee the independence, authority, and resources of the future Anti-Monopoly Enforcement Authority, it should be established as an independent agency at the ministry level. The new agency should carefully allocate its resources, and the enforcement of the AML ideally should rely on deterrence built on correct and clear private expectations of enforcement policy.

Although the AML will be an important tool to carry out China's competition policy reforms, it is not the only one. The AML alone, for example, cannot sufficiently address the problem of administrative monopolies. Other reforms, such as $\mathrm{SOE}$ reforms, market entry liberalization, constitutional and government structure reforms, and improvements to the legal system, will be indispensable to China's goal of promoting competition in its economy. In addition to enforcing the AML, China needs to actively pursue these broader competition policy reforms. The AML is but a beginning. 
HeinOnline -- 75 Antitrust L.J. 266 2008-2009 